\title{
Good Public Governance in Islamic Perspective: An Analysis on the World Governance Indicator in OIC Member Countries
}

\author{
Muhammad Ghafur Wibowo ${ }^{1}$ \\ ${ }^{1}$ Fakultas Ekonomi dan Bisnis Islam, UIN Sunan Kalijaga Yogyakarta, \\ Indonesia \\ *muhammad.wibowo@uin-suka.ac.id
}

\begin{abstract}
Introduction to The Problem: The Organization of Islamic Cooperation, OIC, member countries are considering face similar economic problems, such as economic backwardness, poverty, and unemployment which originated from the low public governance.
\end{abstract}

Purpose/Objective Study: This study seeks to reveal the suitability of Islamic teachings with Good Public Governance, which in recent decades has become a concern of various countries in the world, and its implementation in OIC member countries.

Design/Methodology/Approach: Qualitative analysis was used to explain the World Governance Indicator (WGI) issue from various literature of Islamic teachings. It also added a quantitative descriptive analysis of the implementation of WGI in OIC member countries from 2005-2017.

Findings: There are many matches between the governance index published by the World Bank and the teachings of Islam, based on the Qur'an and the hadith. Practically, OIC has made the issue of good public governance represented by the governance index as a common goal of all its members. However, the facts show that the governance index in various OIC member countries is still relatively low compared to other countries. Therefore, all OIC member countries need to enhance further the implementation of Islamic teachings in the management of the country to produce better governance.

Paper Type: Research Article

Keywords: Good Public Governance; OIC Member Countries

\section{Introduction}

Empirical facts show that Muslim countries (majority Muslim population) are relatively left behind in terms of their economic performance. Based on data published by UNDP, Kuran (2018) revealed gaps in economic

Ihtifaz: Journal of Islamic Economics, Finance, and Banking

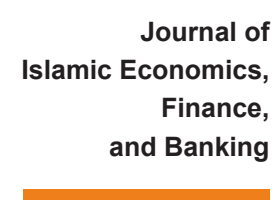

Vol. 3, No. I, Juni 2020 , pp. 51-65, ISSN p:2622-4755 e:2622-4798

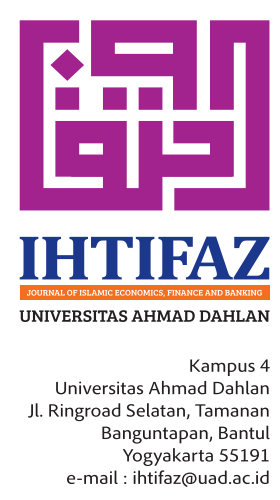


performance indicators between Muslim and non-Muslim majority population countries.

IHTIFAZ - JIEFB

Kuran compared several indicators of the economic performance of countries incorporated in the Organization of Islamic Cooperation, OIC with global data and non-OIC countries in 2014. In terms of the quality of human resources as measured by the Human Development Index, HDI in table 1 shows the lagging which is quite far between the HDI value of Muslim countries (0.61) with the HDI value of the world (0.71) especially with the HDI value of non-Muslim countries (0.74).

In terms of health quality as measured by life expectancy, the achievements of Muslim countries are also lower (66.5 years) than the world data (71.4 years) and non-Muslim countries (72.8). The quality of education in Muslim countries measured by literacy level (reading ability) is also far behind $(73.3 \%)$ of the total world data $(85.2 \%)$, let alone non-Muslim countries (88.9\%). The low quality of human resources in Muslim countries eventually indirectly impacts on their low income per population (GDP per capita) of USD 10,015 per year, far compared to world data (USD 15,740) and non-Muslim country data (USD 17,500 ).

Table 1. Comparison of Economic Performance Indicators for the Muslim Majority Population Countries in 2014

\begin{tabular}{|c|c|c|c|c|c|}
\hline $\begin{array}{l}\text { Region, Country, or } \\
\text { Country Grouping }\end{array}$ & $\begin{array}{l}\text { Population } \\
\text { (millions) }\end{array}$ & $\begin{array}{l}\text { Human } \\
\text { Develop- } \\
\text { ment } \\
\text { Index } \\
(0-1)\end{array}$ & $\begin{array}{l}\text { Life } \\
\text { expectancy } \\
\text { at birth } \\
\text { (years) }\end{array}$ & $\begin{array}{c}\text { Adult } \\
\text { literacy } \\
\text { rate } \\
(\%)\end{array}$ & $\begin{array}{c}\text { Gross } \\
\text { Domestic } \\
\text { Product } \\
\text { Per Capita } \\
\text { (USS, PPP) }\end{array}$ \\
\hline Afghanistan & 31 & 0.47 & 60.4 & 38.2 & 1.934 \\
\hline Arab League & 378 & 0.66 & 70.5 & 779 & 17,428 \\
\hline ASEAN, Muslim-maj. & 283 & 0.69 & 69.5 & 95.4 & 12,809 \\
\hline Balkans, Muslim-maj. & 9 & 0.73 & 75.8 & 98.1 & 10,636 \\
\hline Bangladesh & 159 & 0.57 & 71.6 & 61.5 & 3,332 \\
\hline Ex-USSR, Muslim-maj. & 75 & 0.70 & 69.0 & 99.8 & 12,099 \\
\hline Iran & 79 & 0.76 & 75.4 & 84.6 & 17,365 \\
\hline Non-Arab Africa, Muslim-maj. & 96 & 0.39 & 55.8 & 54.8 & 3,604 \\
\hline Pakistan & 185 & 0.54 & 66.2 & 55.6 & 5,041 \\
\hline Turkey & 76 & 0.76 & 75.3 & 95.4 & 19,618 \\
\hline $\mathrm{OIC}$ & 1,678 & 0.61 & 66.5 & 73.3 & 10,015 \\
\hline World & 7,347 & 0.71 & 71.4 & 85.2 & 15,740 \\
\hline Non-OIC & 5,669 & 0.74 & 72.8 & 88.9 & 17,500 \\
\hline ASEAN, Muslim-min & 274 & 0.64 & 70.6 & 93.8 & 8,417 \\
\hline Balkans, Muslim-min & 59 & 0.81 & 76.3 & 98.0 & 20,693 \\
\hline Chima & 1,371 & 0.73 & 75.8 & 95.1 & 14,238 \\
\hline Ex-USSR, Muslim-min. & 71 & 0.76 & 71.8 & 99.7 & 10,832 \\
\hline India & 1,311 & 0.61 & 68.0 & 69.3 & 6,088 \\
\hline Latin America & 633 & 0.75 & 75.0 & 92.6 & 15,581 \\
\hline Non-Arab Africa, Muslim-min. & 859 & 0.52 & 58.7 & 65.3 & 3,907 \\
\hline OECD (except Turkey) & 1,204 & 0.88 & 80.8 & 99.8 & 42,216 \\
\hline Russia & 143 & 0.80 & 70.1 & 99.7 & $24,451]$ \\
\hline
\end{tabular}

Source: UNDP, Human Development Report 2015, in Kuran (2018)

The backwardness in the economy of Muslim-majority countries from other countries has long been a study of Muslim thinkers. Monzer Kahf analyzes some of the leading causes of the problem, such as 
corruption and futile government spending, price subsidies, inefficiency in the substantial public sector, and significant defense spending (1997).

A similar assessment was presented by Lackey when analyzing why Islamic countries are endowed with abundant natural resources and resources, but fail to develop their economies properly (2013). Muslim countries in the Middle East, North Africa, South Asia, and Southeast Asia, in general, have abundant natural resource wealth, such as oil and gas. However, they are far behind from countries that do not have sufficient wealth of resources, such as the Netherlands, Switzerland, and other developed countries. According to Lackey, weak education, security instability, and fragile legal certainty are the leading causes of the problem. Besides, the fate of women who left behind in various aspects of life also adds the weight of the condition. Moreover, institutionally, poor public services and high levels of corruption further aggravate the economic downturn in Muslim countries.

As a form of development of thought and response of Muslim countries to the development of world community life, in 2008, the OIC amended the OIC Charter. This organization not only cooperates in the economic, social, religious, and knowledge fields as it has been running but also develops further in various areas of life (S. Hasan et al., 2012). The OIC is trying to harmonize its activities with numerous other international organizations, especially the United Nations (UN). Current global issues such as human rights, gender equality, justice, terrorism are explicitly included in the amendment of the charter. These issues are involving the joint efforts of the OIC countries to create good governance in their respective countries to achieve a better life. The problems of democracy, law enforcement, fighting corruption, and security conflicts are a common concern of all OIC countries (OIC, 2008).

This study seeks to reveal the compatibility of Islamic teachings with the concept of Good Public Governance (GPG) represented by the Governance Index developed by the World Bank. Furthermore, this study also shows the link between governance index and economic performance (income per capita) in Muslim countries incorporated in the Organization of Islamic Cooperation, OIC. The reason is considering that OIC countries face similar economic problems, such as economic backwardness, poverty, unemployment, etc. (Kuran, 2018).

\section{Research Method}

This research is a qualitative research that aims to explain the phenomenon by collecting qualitative data from various sources. However, this study also uses quantitative data presented descriptively to provide a clearer and more empirical understanding (Sekaran \& Bougie, 2016). Qualitative sources come from various literature that links the values of Islamic teachings and the idea of good governance. The quantitative data are from the World Bank and related research results. 
In general, there are two methods in developing the idea of good Islamic governance that is currently emerging. First, the method of extracting directly from the Qur'an and the hadith of the Prophet is related to good management of institutions/organizations (ranging from monotheism, sharia, shura, ihsan, and so on). The second method is to examine the principles of good governance that currently exist and see their compatibility with the Islamic values of the Qur'an and the hadith. This research applies the second method to produce harmony between Islamic teachings and the concept of Good Public Governance.

\section{RESULTS AND DISCUSSION}

\section{Good Governance in Islamic Perspective}

The term Good Corporate Governance (GCG) is relatively more widely known and practiced by various parties, both private and government. In fact, in addition to the term GCG, there is also the term Good Public Governance (GPG), which is defined as a system or code of conduct related to the management of authority by state administrators in carrying out their duties responsibly and accountably (KNKG, 2008).

According to Hasan (2009) and Hafeez (2013), the concept of governance, both corporate and government, must be based on the value of Islamic monotheism which is sourced from the holy book: "(i.e.) those who remember Allah while standing or sitting or in a state of lying down and they think about the creation of heaven and earth (while saying) "O our Lord, Thou hast not created this in vain, Blessed is Thou, then protect us from the torments of hell" (QS. Al-Ma'idah [3]: 191). Monotheistic values that underlie all human activities, both individually and communally, both in terms of worship and muamalah (human relations) (Z. Hasan, 2009).

The value of monotheism or tauhid is what then raises the value of ihsan or the value of goodness: "And surely Allah is true with those who do good" (QS. Al-'Ankabut [29]: 69). Ihsan or good deeds are the implementations of monotheism to Allah SWT, as the hadith of the Prophet SAW: "... He (Gabriel) asked again: "Tell me about ihsan". The Prophet (PBUH) replied, "You should worship Allah as if you saw Him. Even if you don't see Him, surely He sees you" (Khan, 2019).

After being based on a strong monotheism basis, then at the operational level, there needs to be a sharia council as the top of the highest institutional governance. The idea of the sharia council was raised by Choudhury in some of his writings when contextualizing corporate governance from an Islamic perspective (Alam Choudhury \& Hoque, Ziaul, 2006). The sharia board has to provide advice or consultation (whether requested or not) to the executive board (in business, public, and social organizations). The whole series is directed to create people's welfare in line with Islamic sharia values. 
Figure 1. Tawhid and Shura Approach in Governance
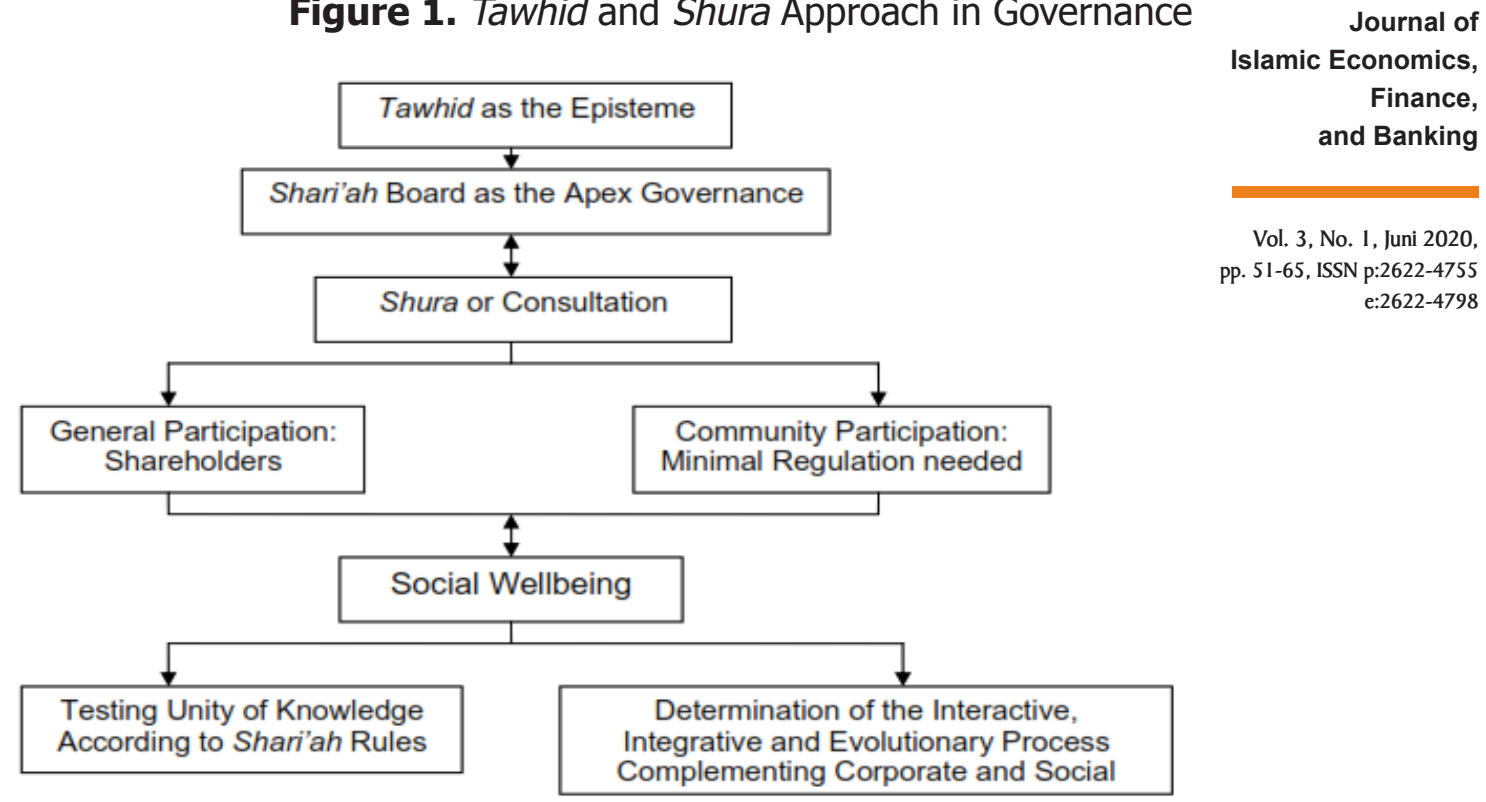

Vol. 3, No. 1, Juni 2020 , pp. 51-65, ISSN p:2622-4755 e:2622-4798

Source: Hasan, (2009)

If we examined in more detail and depth, we would indeed find many verses in the Qur'an and the hadith of the Prophet SAW that are in line with the fundamental values of good governance. Ahsan et al. (2017) published a book entitled "Qur'anic Guidance for Good Governance", while Aziz and Ambreen published articles that revealed the results of searches of the Qur'an and the hadith of the Prophet SAW. Some of these references find good governance values such as justice and equity, reformation of society, the rule of law, Islamic democracy, education, zakat, and the welfare state (Aziz \& Ambreen, 2017). By originating from the Qur'an and the hadith as well, it can be carried out a more comprehensive study of ontology and epistemology of Islamic governance (Malik, 2017).

To obtain a more accurate description, we need a precise model of how good governance in Islam, one of which is reflected in the leadership of the prophets. Naqvi et al. provide a more tangible picture of ideal leadership models as a form of implementing good governance, referring to the leadership of the prophet. The prophet's leadership was not limited to the Prophet Muhammad, but also previous prophets such as Solomon, Moses, David, Joseph, and so on. The whole story of the leadership of the prophets is found in the Qur'an (Naqvi et al., 2011).

Practically, several studies reveal and analyze the practice of good governance from the perspective of Islam in various fields of life. Saidon et al. (2019) examine the principles of good family governance from an Islamic perspective, which is sourced from the Qur'an and the hadith of the prophet. The fundamental values of good family governance include vicegerency, transparency; responsibility; and accountability.

Good governance can also be applied in the management of charity or social institutions, as conducted by Ghafran and Yasmin, who researched several Islamic-based charitable institutions in the UK. The basic principles of good governance consist of individual aspects of managers (shidiq, amanah, tablig, istiqamah, mas'uliyyah, ihsan) as well as institutional aspects (fair, trustful, istisla, falah, iqtishad, ihsan). The research 
shows that there is a gap between good individual quality and suboptimal institutional quality (Ghafran \& Yasmin, 2019).

In the banking sector, many companies have applied GCG (good corporate governance) principles in their operational activities. Furthermore, some introduce sharia governance principles in the sharia banking industry. The primary thought of sharia governance is that Islamic spiritual values can be implemented in sharia banking practices, including in the case in Indonesia (Setyowati, Abubakar, \& Rodliah, 2017).

Muslim researchers and thinkers continue to develop ideas of good governance from the perspective of Islam in various fields of life, even though it is still partial or individual. In the context of law enforcement, Mahmod found compatibility between Islamic teachings and the concept of law enforcement contained in the Charter of the United Nations (UN) (Mahmod, 2013). In the context of public sector services in Indonesia, Wiryanto analyzed the implementation of good governance (GG), which refers to the guidelines of the United Nations (UN) with Islamic teachings. Wiryanto found $8 \mathrm{GG}$ principles that are in line with Islamic values: 1) participation-ta'awun; 2) rule of law-syari'ah; 3) transparencybayan; 4) responsiveness-tabayyun; 5) consensus orientation-syura; 6) equity \& inclusiveness-adl; 7) effectiveness \& efficiency-itqan \& tawazun; 8) accountability-mas'uliyyah (Wiryanto, 2018).

So far, there has been no agreement between Muslim thinkers and Islamic businesspeople regarding the ideal form of good governance from an Islamic perspective. Each thinker has a view and understanding that are not infrequently different from one another. Therefore, until now, there has not been a standard model applied and is a reference for every institution that wants to implement good governance according to Islam (Islamic/sharia good governance) (Uddin, 2015).

\section{Good Public Governance and the World Governance Indicator in Islamic Perspective}

In 1992, the World Bank published a book entitled "Governance and Development". The book highlights the quality of institutions in various developing countries in using their resources to improve the welfare of their people. The term governance was relatively new at the time, although studies on the quality of institutional management began in the 1960s. The World Bank has a concern for governance because of its useful role in encouraging efforts to increase development (The World Bank, 1992). This idea is the beginning of the development of the concept of Good Public Governance (GPG).

The World Bank in that book defines the term governance as a way in which power is used in the management of a country's economic and social resources for development. When compared, the principles or principles between good corporate governance and good 
public governance are almost the same. It shows that the two types of governance are essential for the economic development of society from two different sides, the business world and the government. The implementation of good governance in various countries (including Indonesia) is in line with the basic ideas developed by the World Bank. The World Bank develops governance index through the World Governance Indicator (WGI).

There are 6 dimensions of good governance derived from 3 aspects at the beginning, viz (Kaufmann, Kraay, \& Zoido-Lobaton, 1999):

1. Voice and Accountability (VA): capture the perceptions of citizens of a country regarding their involvement in government elections, freedom of expression, freedom of association, and media freedom.

2. Political Stability and Absence of Violence/Terrorism (PS): capture public perceptions regarding the instability of the situation or efforts to overthrow the government through actions that cannot be justified, such as violence or terrorism that are motivated by political interests.

3. Government Effectiveness (GE): capture the perception of the quality of public services, the quality of civil services, and the degree of freedom from political pressure, the quality of policy formulation and implementation, and also the credibility of the government's commitment to the various policies it makes.

4. Regulatory Quality (RQ): capture perceptions of the government's ability to develop and implement policies and regulations that encourage private sector development.

5. Rule of Law (RL): capture perceptions of people's trust and acceptance of various types of regulations, particularly related to law enforcement, property rights, police, and courts.

6. Control of Corruption (CC): capture public perceptions regarding the supervision and enforcement of corrupt practices, both small and large, carried out by political elites and private parties.

The six indicators in the governance index are basically in line with the teachings of Islam, which are held by the majority of the population in OIC member countries. The six indicators have the same views as the verses of the Qur'an and the hadith of the Prophet Muhammad. The description of the compatibility between the governance index and Islamic teachings is as follows:

1. Voice and Accountability: Islam gives freedom to its adherents to be free to express and speak as long as it contains goodness (QS. Al-Baqarah [2]: 83). One of the best forms of jihad is to speak the truth in the face of a wrongdoing leader (HR. Abu Dawud) (Saeed, 2013). Likewise, the values of accountability and democracy are 
very much in line with the teachings of Islam, which teaches to always discuss every problem openly with deliberations among the people. (QS. Ali Imran [3]: 159; QS. Asy-Syu'ara [26]: 38) (Khatab \& Bouma, 2007). Dissent is not prohibited, including criticizing the government through demonstrations, as a form of democracy in the state (Said \& Khairuldin, 2017), as long as it does not lead to liberal democracy, which gives unlimited freedom (Mubarak, 2016).

2. Political Stability and Absence of Violence/Terrorism: Some Muslim-populated countries are currently experiencing internal and external conflicts that have resulted in violence (war). Often there is a view that Islam teaches violence to its people, even though other religions also "teach" violence (Esposito, 2015). This condition occurs because religious beliefs can justify someone to commit acts of violence, even a necessity when defending their religion (Tarlow, 2015). When, in fact, the violence allowed in Islam is a reaction to the attacks of other parties (QS. Al-Baqarah [2]: 192). When the enemy wants peace, it must be responded with peace as well (QS. Al-Anfal [8]: 61), even prisoners of war must be treated well (QS. Muhammad [47]: 4). At this time, acts of violence (terrorism) in the name of religion in many Muslim countries have arisen because there are also other causes such as politics (al-Qaeda) and the economy (Boko Haram) (Karlsson \& Nilsson, 2015). Of course, this is very contrary to the teachings of Islam, which states that killing one person without the truth is tantamount to killing all humans (QS. Al-Ma'idah [5]: 32).

3. Government Effectiveness and Regulatory Quality: According to Borhan (2015), Prophet Muhammad was sent to the world to be a mercy to the universe (QS. Al-Anbiya' [21]: 107), including also to create a good life (QS. An-Nahl [16]: 97) and welfare of the people (QS. Al-Hajj [22]: 77). Basically, in the teachings of Islam, a leader is a servant of his people (HR. Ibnu Asakir, Abu Nu'aim). The country's leaders are expected to carry out their obligations in the form of effective policies to improve the welfare of the community (QS. AlAnbiya' [21]: 73) (Taufiq, 2015). Therefore, a good government in the teachings of Islam is a compelling government in improving the welfare of its people through quality regulations that encourage the developing business world (Al-Jarhi, 2017).

4. Rule of Law: Various regulations made by the state must be strictly enforced in order to create justice (QS. Al-Ma'idah [5]: 8). With the creation of rules and law enforcement in various aspects of life, community order will be created (Gutmann \& Voigt, 2018), also increased overall economic activity (Gouda, 2013). Multiple tools in law enforcement, such as the police and judicial institutions, are essential in efforts to create justice. Therefore, Islamic teachings strongly support law enforcement and regulatory initiatives in various aspects of life (Ahmad, 2013). 
5. Control of Corruption: Islam expressly forbids corruption in its various forms because it is a form of sleaze (QS. Al-Baqarah [2]: 188), and the results of corruption are illegitimate or haram assets (QS. Al-Ma'idah [5]: 42) (Arafa, 2012). One of the hadiths of the Prophet Muhammad SAW tells about the tax collector and then received extra gifts from taxpayers who were later banned by the Prophet, showing that Islam strictly prohibits bribery as a form of corruption (Iqbal \& Lewis, 2006). Today, some Muslim countries are severely affected by corruption, including in the Middle East region (Er, 2008). However, the actual teachings of Islam strongly oppose the search for property in a vanity through corruption. Muslims who understand the teachings of their religion should avoid various forms of corrupt practices (Al-Momani, 2015).

\section{Empirical Evidence of Governance Index in OIC Member Countries}

A repot from the Asian Development Bank in 2013 shows the relationship between the six measures of governance index and GDP per capita of all countries in the world (187 countries) in 2011 (Asian Development Bank, 2013). Figure 2 shows the relationship between the governance index (Regulatory Quality/RQ and Voice and Accountability/VA) and GDP per capita. There is a direct relationship between the two measures of the governance index and GDP per capita. The better the index of regulation quality and freedom of speech and accountability in a country, the higher the GDP per capita the country will achieve.

Figure 2. Relationship between Governance Index (RQ \& VA) and GDP per capita
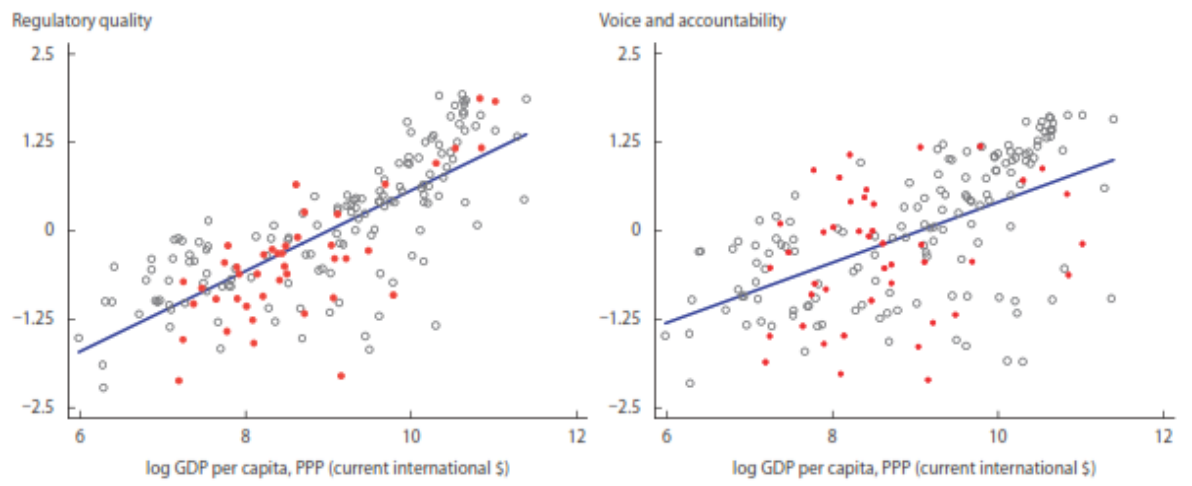

Source: Asian Development Bank (2013)

Figure 3 shows the relationship between governance index (Political Stability and Absence of Violence-Terrorism/PS and also Control of Corruption/CC) on GDP per capita. There is a direct relationship between the two sizes of governance index with GDP per capita. The higher the 
value of PS and CC index in a country, the higher the GDP per capita the country will achieve.

\section{IHTIFAZ - JIEFB}

Figure 3. Relationship between Governance (PS \& CC) and GDP per capita
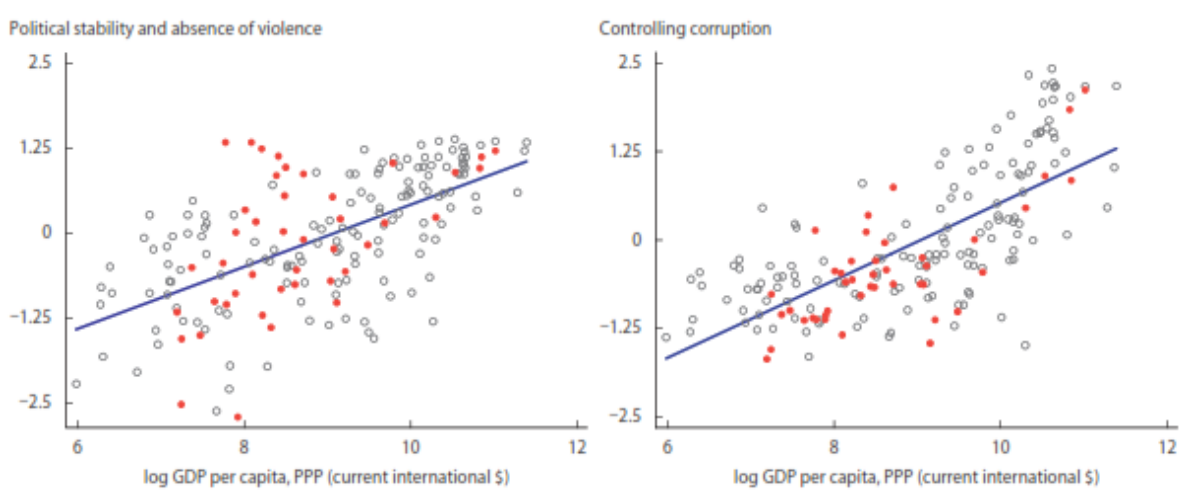

Source: Asian Development Bank (2013)

Figure 4 shows the relationship between the governance index (Government Effectiveness/GE and the Rule of Law/RL) on GDP per capita. There is a direct relationship between the two measures of the governance index and GDP per capita. The better of GE and RL index in a country, the higher GDP per capita the country will achieve.

Figure 4. Relationship between Governance Index (GE \& RL) and GDP per capita
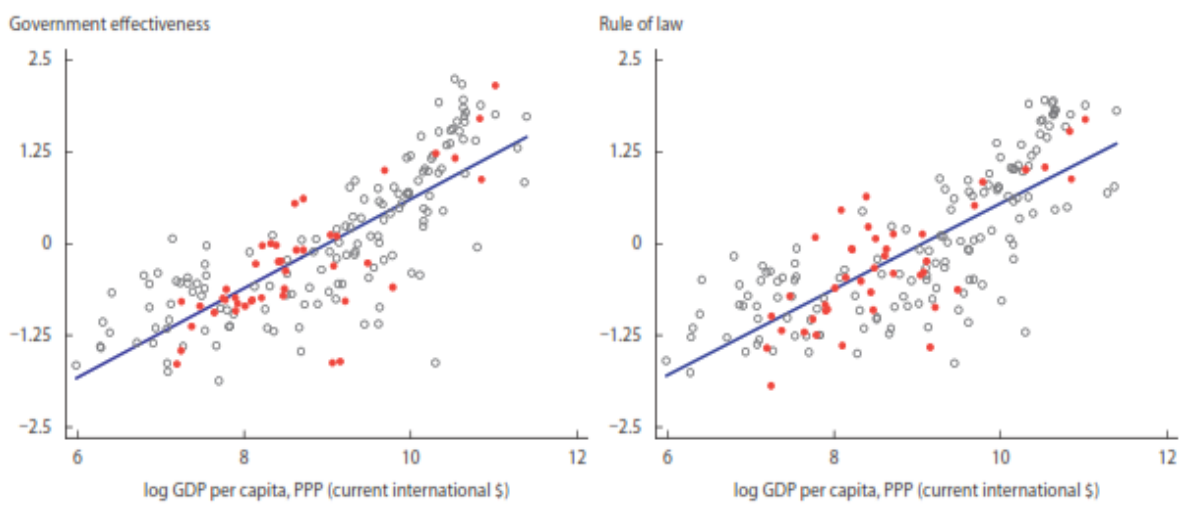

Source: Asian Development Bank (2013)

The six graphs presented by the Asian Development Bank (ADB) show the strong relationship between the governance index (consisting of six measures) and economic growth achieved by 187 countries in the world. That is, the quality of governance in Muslim countries (members of the Organization of Islamic Cooperation, OIC) dramatically influences the achievement of their GDP per capita. Various efforts to improve 
the welfare of the population in Muslim countries, one of which can be started from efforts to improve the quality of governance.

The amendment to the OIC Charter in 2008 is a step forward for this organization. OIC member countries recognize the importance of various international issues that have already been echoed by many other international organizations, such as the United Nations, the World Bank, and so on. The OIC is fully aware that good governance in the

Journal of Islamic Economics, Finance, and Banking

Vol. 3, No. I, Juni 2020 , pp. 51-65, ISSN p:2622-4755 e:2622-4798 context of governance is an essential factor in efforts to encourage the improvement of the welfare of Muslims (OIC, 2008). Explicitly stated in Article 2 Paragraph 6 of OIC Chapter, all OIC members must participate in upholding and advancing the issues of good governance, democracy, human rights, basic freedoms, and law enforcement in various aspects of state life: "The Member States shall uphold and promote, at the national and international levels, good governance, democracy, human rights and fundamental freedoms, and the rule of law."

The firmness of the members' attitudes in the amendment to the OIC Charter can normatively encourage the implementation of various aspects of the governance index. However, the governance index did not experience significant changes in the period after the amendment. The average governance index values (of the six governance indices) of OIC countries can be seen in the following figure 5 :

Figure 5. Average of Governance Index in 2005-2017

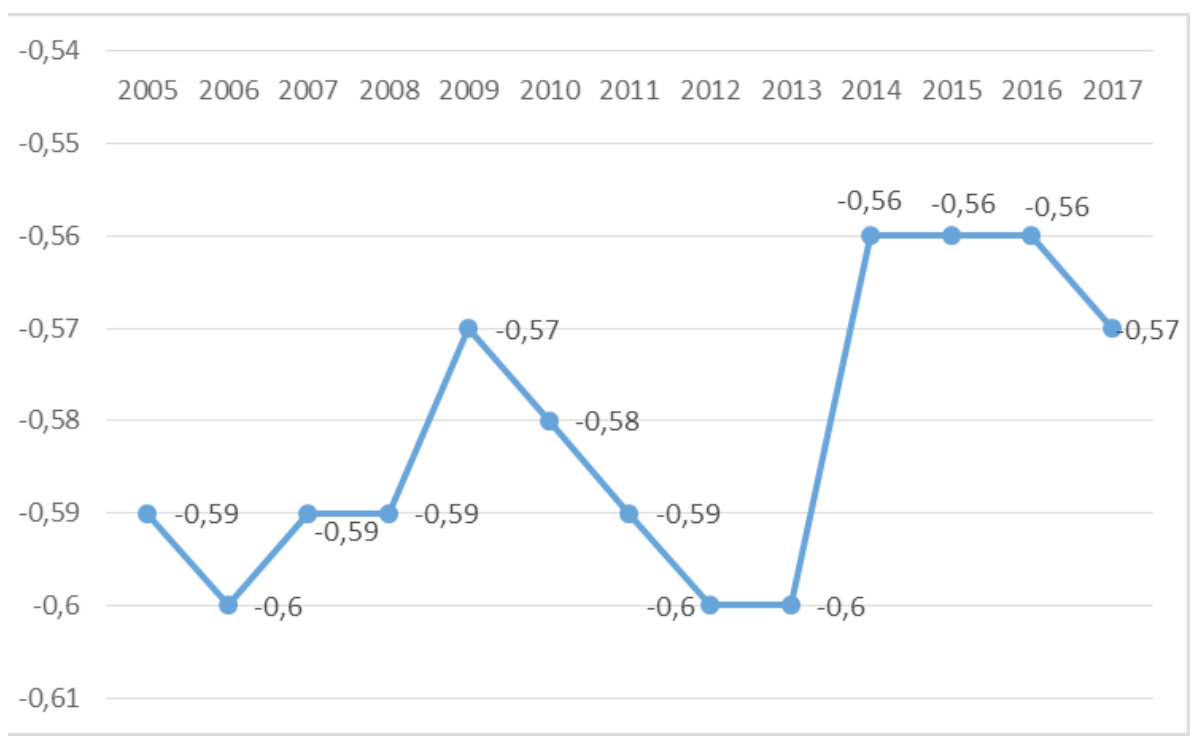

The governance index score ranges from -2.5 to 2.5 , which indicates better quality at a higher value. Figure 5 shows that the average governance index scores of all OIC member countries show low scores. A negative average value $(<0)$ indicates the poor quality of governance in these OIC countries. 
The governance index values in the period before and after 2008 were no significant changes. It must be realized that improving IHTIFAZ - JIEFB governance is a very fundamental systemic change; therefore, it cannot be done instantly and quickly. However, the role of the OIC as a forum for Muslim-populated countries that explicitly encourages the creation of more governance must continue to be improved. The OIC cannot feel enough with just an agreement and appeals for its member countries, but evaluation and improvement must continue to be pursued (Bacik, 2011). In this way, the OIC will have a role in improving the quality of governance in all member countries.

\section{Conclusion}

Islamic teachings sourced from the Qur'an and the hadith of the Prophet have explicitly or implicitly taught the importance of good governance at the company or country level. At the country level, the concept of Good Public Governance (GPG) is internationally recognized by the World Bank with a governance index. The six governance indexes published by the World Bank are very relevant to Islamic teachings sourced from the Qur'an and hadith. Empirically also found a close relationship between the governance index with a country's per capita income. But unfortunately, in the context of OIC member countries, the average governance index value is still meager compared to other groups of countries. OIC has agreed on efforts to improve governance since 2008. Therefore, OIC member countries must enhance the campaign further to implement Islamic teachings that are very parallel with the values of good governance.

\section{Acknowledgment}

This research is part of the author's dissertation on the Islamic Economics doctoral program, Sunan Kalijaga State Islamic University, 2020. The author thanks the Supervisor Prof. Dr. Hadri Kusuma and Dr. Ibnu Qizam for all directions and suggestions.

\section{References}

Ahmad, M. R. (2013). Penegakan Hukum Atas Keadilan dalam Pandangan Islam. Mizan, Jurnal Ilmu Syariah, 1(2), 143-148.

Al-Ahsan, A., Hunter, N. D., Moten, A. R., Young, S. B., Zakaullah, M. A., Kamaruddin, Z., \& Islam, S. S. (2017). Qur'anic Guidance for Good Governance: A Contemporary Perspective (A. Al-Ahsan \& S. B. Young, eds.). Delaware: Palgrave Macmillan.

Al-Jarhi, M. A. (2017). The Islamic Political System: A Basic Value Approach. MPRA Paper No. 72706, (74924). 
Al-Momani, M. (2015). Economic Corruption and Treatment, Perspectives of Islam and Capitalism (Comparison study). Journal of Economics and Development Studies, 3 (3), 123-134. https://doi.org/10.15640/ jeds.v3n3a11

Alam Choudhury, M., \& Hoque, Ziaul, M. (2006). Corporate Governance in Islamic Perspective. Corporate Governance International Journal of Business in Society, 6 (2), 116-128. https://doi.org/10.1108/ IMEFM-10-2012-0101

Arafa, M. (2012). Corruption and Bribery in Islamic Law: Are Islamic Ideals Being Met in Practice? Annual Survey of International \& Compliance Law, 18 (1), 171-242.

Asian Development Bank. (2013). Asian Development Outlook 2013 Update: Governance and Public Service Delivery. Manila: Asian Development Bank.

Aziz, K., \& Ambreen, S. (2017). Roadmap for Ensuring Good Governance in Islamic Perspective. FWU Journal of Social Sciences, 11(1), 331-339.

Bacik, G. (2011). The Genesis, History, and Functioning of the Organization of Islamic Cooperation (OIC): A Formal-Institutional Analysis. Journal of Muslim Minority Affairs, 31(4), 594-614. https:// doi.org/10.1080/13602004.2011.630864

Er, M. (2008). Corruption from the Islamic Perspective: Some Recommendations for the MENA Region. International Journal of Islamic and Middle Eastern Finance and Management, 1(1), 31-51. https://doi.org/10.1108/17538390810864241

Esposito, J. L. (2015). Islam and Political Violence. Religions, 6 (3), 1067-1081. https://doi.org/10.3390/rel6031067

Ghafran, C., \& Yasmin, S. (2019). Ethical Governance: Insight from the Islamic Perspective and an Empirical Enquiry. Journal of Business Ethics. https://doi.org/10.1007/s10551-019-04170-3

Gouda, M. (2013). Islamic Constitutionalism and Rule of Law: A Constitutional Economics Perspective. In Constitutional Political Economy (Vol. 24). https://doi.org/10.1007/s10602-012-9132-5

Gutmann, J., \& Voigt, S. (2018). The Rule of Law and Islam. In ILE WP Series, No. 13. https://doi.org/10.4337/9781786432445.00030

Hafeez, M. M. (2013). An Analysis of Corporate Governance in Islamic and Western Perspectives. International Journal of Business, Economics, and Law, 2(3), 98-103.

Hasan, S., Odhiambo, G., Qaydi, S. Al, Quddus, A., Moniruzzaman, Chowdhury, A., \& Tadjoeddin, M. Z. (2012). The Muslim World in the 21st Century (S. Hasan, ed.). https://doi.org/10.1017/ CBO9781107415324.004 
Hasan, Z. (2009). Corporate Governance: Western and Islamic Perspectives. International Review of Business Research Papers, 5 (1), 277-293.

Imran Haider Naqvi, Aziz, S., Zaidi, S. A. H., \& Kashif-ur-Rehman. (2011). The Model of Good Governance in Islam. African Journal of Business Management, 5(27), 10984-10992. https://doi.org/10.5897/ ajbm10.1416

Iqbal, Z., \& Lewis, M. (2006). Governance and Corruption: Can Islamic Societies and the West Learn from Each Other? The American Journal of Islamic Social Sciences, 19(2), 1-33.

Joni Tamkin Bin Borhan, C. (2015). Economic Functions of The State: An Islamic Perspective. Jurnal Usuluddin, Volume 16(Issue 16).

Kahf, M. (1997). Instruments of Meeting Budget Deficit in Islamic Economy. IRTI Research Paper, 42.

Karlsson, M., \& Nilsson, M. (2015). Islamic Terrorism: A Qualitative, Comparative Case Study between Al-Qaeda and Boko Haram. Linnaeus University.

Kaufmann, D., Kraay, A., \& Zoido-Lobaton, P. (1999). Governance Matters. Policy Research Working Paper, (2196), 1-70.

Khan, M. A. M. (2019). Islam and Good Governance. https://doi. org/10.1057/978-1-137-54832-0

Khatab, S., \& Bouma, G. D. (2007). Democracy In Islam (Routledge Studies in Political Islam). In Routledge. Retrieved from http:// www.amazon.com/Democracy-Islam-Routledge-Studies-Political/

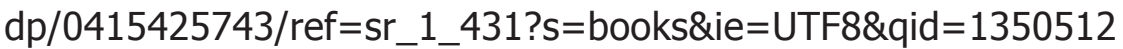
$142 \& s r=1-431 \&$ keywords $=$ qutb

KNKG. (2008). Pedoman Umum Good Public Governance Indonesia. https://doi.org/10.1021/ic035198d

Kuran, T. (2018). Islam and Economic Performance: Historical and Contemporary Links. Journal of Economic Literature, 56(4), 12921359.

Lackey, R. (2013). Why Have the Islamic Countries Failed To Develop Even With Resources Like Oil, While Countries With No Resources Like Switzerland Have Flourished? Retrieved January 20, 2020, from Forbes website: https://www.forbes.com/sites/quora/2013/01/08/ why-have-the-islamic-countries-failed-to-develop-even-withresources-like-oil-while-countries-with-no-resources-likeswitzerland-have-flourished/\#295b6023282c

Mahmod, N. A. K. N. (2013). Good Governance and The Rule of Law. The First International Conference on Law, Business and Government, I.45-I.55. https://doi.org/10.1093/oso/9780198841159.003.0005

Malik, M. (2017). Foundations of Islamic Governance. https://doi. org/10.4324/9781315414652 
Mubarak, A. (2016). Democracy from Islamic Law Perspective. KOM, V(3), 1-18. https://doi.org/10.5937/kom1603001M

OIC. Charter of the Organisation of Islamic Cooperation. , (2008).

Saeed, R. A. (2013). Quranic Concept of Freedom of Expression : A descriptive Study in Modern Socio-Political Perspective. Al-Qalam, 18(1), 70-88.

Said, N. A., \& Khairuldin, W. M. K. F. W. (2017). Freedom of Speech in Islam and its Connection with Street Demonstrations. International Journal of Academic Research in Business and Social Sciences, 7(4), 122-129. https://doi.org/10.6007/ijarbss/v7-i4/2792

Saidon, R., Mara, U. T., Ismail, C. Z., Mara, U. T., Zaid, M., Zin, M., ... Mara, U. T. (2019). Analyzing the Principles of Good Family Governance from the Islamic Law Perspective. Journal of Legal, Ethical and Regulatory Issues, 22(3), 1-8.

Sekaran, U., \& Bougie, R. (2016). Research Methods for Business (7th ed.). West Sussex: John Wiley \& Son.

Setyowati, R., Abubakar, L., \& Rodliah, N. (2017). Sharia Governance on Islamic Banking: Spiritual Rights Perspective on Consumer Protection in Indonesia. Diponegoro Law Review, 2(1), 227-248. https://doi. org/10.14710/dilrev.2.1.2017.227-244

Tarlow, P. E. (2015). Religion, Violence, and Terrorism. International Journal of Safety and Security in Tourism and Hospitality, 12(1), 48-56. Retrieved from https://search.proquest.com/docview/16 73049374?accountid=11862\%0Ahttp://openurl.ac.uk/ukfed:kcl. ac.uk?url_ver=Z39.88-2004\&rft_val_fmt=info:ofi/fmt:kev:mtx:jou rnal\&genre=article\&sid=ProQ:ProQ\%3Aeducation\&atitle=Religion $\% 2 \mathrm{C}+$ Violence $\% 2 \mathrm{C}+$ and + Terrorism\&title $=\mathrm{S}$

Taufiq, I. (2015). Transparency and Accountability in The Qur'a and Its Role in Building Good Governance. International Journal of Business, Economics and Law, 6(4), 73-81.

The World Bank. (1992). Governance and Development. Washington: A World Bank Publication.

Uddin, M. A. (2015). Governance from Islamic Economic Perspective: A Shari'ah Governance Framework. Munich Personal RePEc Archive (MPRA), (67695). https://doi.org/10.1016/j.bmcl.2007.05.104

Wiryanto, W. (2018). The Comparison of Unescap's Characteristics of Good Governance and Islamic Characteristics of Governance for Public Services Reform in Indonesia. Hasanuddin Economics and Business Review, 2(2), 123-141. https://doi.org/10.26487/hebr. v2i2.1545

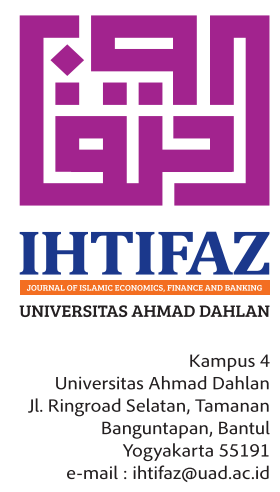

